Type of the Paper (Review)

\title{
Spiritual care for increasing the quality of nursing service in 21st Century: A review
}

\author{
Endang Sri Purwanti Ningsih ${ }^{1^{*}}$, Moses Glorino Rumambo Pandin ${ }^{2}$
}

Corresponding Authors: Endang Sri Purwanti Ningsih, Student at Faculty of Nursing, Universitas Airlangga, Email : endang.sri.purwanti-2020@fkp.unair.ac.id, Affiliation: ${ }^{1}$ Student at Faculty of Nursing, Universitas Airlangga

${ }^{2}$ Lecture at Faculty of Humanities, Universitas Airlangga

\begin{abstract}
Holistic care in the nursing care consists of physical, psychological, socio-cultural, developmental and spiritual aspects. However, the spiritual has received less attention than the other four aspects. The aim of this study was to review paper related to spiritual care in nursing care practices. The method in this study is a review using the CINAHL database. CINAHL was used because the articles focus on nursing topics. The keywords used were "Spirituality" OR "Spiritual care" OR "Spiritual" AND "Nurse". The inclusion criteria for the article were English language and published from 2019-2021, for adult range between 18-44 years old. Exclusion criteria were article not in English language, not full paper article, not in Human and not psychometric study also master thesis. This study recorded 64 articles, screened according to the topic, then the final results recorded 19 articles. This article focuses on the use of spiritual care in patients, nurses and caregivers, as well as both of patients and caregivers. The results of the review showed that spiritual care was important for mental health, physical health, and well-being, quality of life, increasing expectations for patients, nurses or caregivers. The significance of the study was spiritual care should be addressed in nursing care practices and it must include in the nursing curriculum, because spiritual care has many benefits for patients and nurses.
\end{abstract}

Key words: nursing care, spiritual care, nurse, spiritual 


\section{Introduction}

\section{Background}

The nursing care process commits to use a holistic care comprehensively to all patient needs (1) .Holistic care consists of physical, psychological, socio-cultural, developmental (life experience) and spiritual aspects (2). Several studies have stated that the spiritual has received less attention compared to the other four aspects (3)(4). So the holistic care in nursing and nursing care has not been achieved and implemented optimally.

Spiritual care is still defined as religious activities such as praying or reading holy book(5)(6). According to NANDA International Nursing Diagnosis, spirituality is a valuable experiencing to get meaning in life through good connectedness with self, others, art, music, literature, and nature (6). In addition it is an important part of human life (7) (8). Meanwhile, spiritual care is an intervention to support spiritual application to patients or clients(9). Further, spiritual care is a code of ethics in nursing as well as nursing guideline (10).

The definitions of religion and spiritual are still being debated. Previous research states that patients are more likely to perceive spirituality as religious activity (11). So spiritual definitions and spiritual concepts are needed. Previous studies showed that there was a little evidence base related to spirituality in the nursing care (11)(12). Spiritual care is needed in nursing care practices such as NP (nurse practitioners) and SNs (specialty care nurses). In addition spiritual can make balance relationship between self, others and the environment (12).

Spiritual care is needed by clients or patients to improve their quality of life as well as meaning of life. Spiritual is necessary for all ages and all circumstances of the client's condition (13)(14). Spiritual care is also needed to increase mental health, such as decreasing depression level, anxiety as well as stress(15) (16). Lack of spiritual care by health care providers is associated with poor quality of life and dissatisfaction in nursing care as well as low well-being (16)(17). Previous study showed that there were still many clients who reported that spiritual care was not provided by nurses (11).

\section{Aim of the study}

Based on this background, the objective of this study was to review the studies about spiritual care in nursing care, so it can be expected as the guideline of nursing care to achieve holistic care.

\section{Research question}

What are the results of the review related to spiritual care papers between 2019 and 2021 ? 


\section{Methods}

This study was a review and conducted for quantitative research. This study following the guideline for Preferred Reporting Items for Systematic Review and Meta-Analyzes (PRISMA) (19) and using previous study for guiding the review (20). This study using CINAHL database for searching spiritual care original study. CINAHL is used because the articles focus on nursing topics. The keywords used were "Spirituality" OR "Spiritual care" OR "Spiritual" AND "Nurse". The inclusion criteria for the article were English language and published from 2019-2021, for adult range between 18-44 years old. Exclusion criteria were article not in English language, not full paper article, not in human and not in psychometric study also master thesis. The data extraction process showed in figure 1. In this review we got 64 articles through CINAHL database. Then, we removed duplicated articles, screening on tittle and abstract. The final records included 19 articles. These articles were focused on the function of spiritual care among patients, nurses, and care giver as well as both of patients and caregivers. Tables were used to assist overview the spiritual care study. Table consist of author and year of the study published, country, sample, setting, design of study and focus of study (table 1-3). We write down the conclusion and review for each study. 


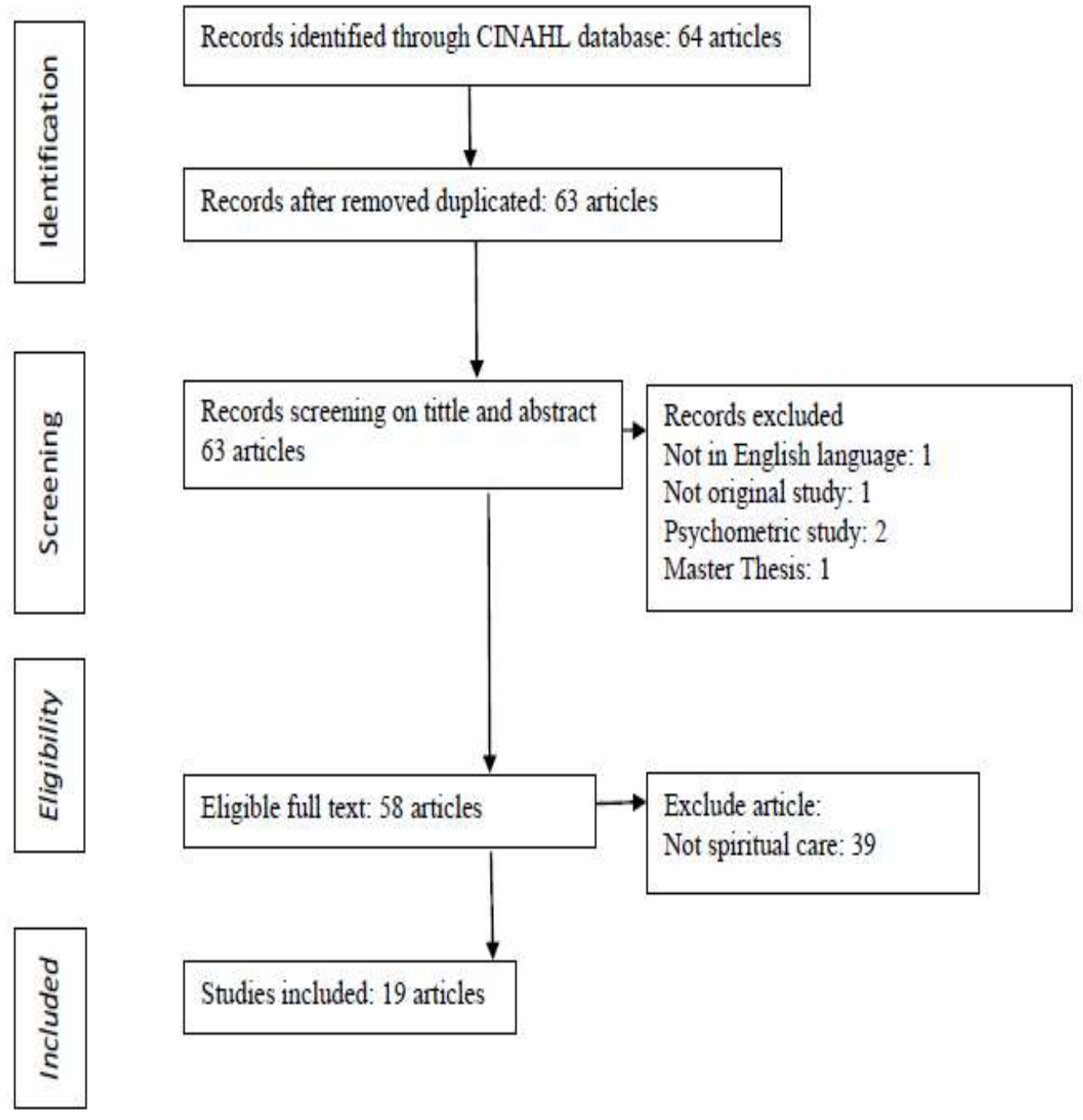

Figure 1. Flow chart of the study 


\section{Results}

Patients

The review showed that 10 articles focused on the spiritual care among patients (table 1). The studies come from Iran (2 articles), USA (2 articles), Netherlands (1 article), Indonesia (1 article), ROC (1 article), Portugal (1 article), Thailand (1 article), and Australia (1 article). The majority of studies were conducted at hospital ( 7 articles). In addition the majority of articles focus on patients with cancer who conducted palliative care (5 articles) and using qualitative design ( 7 articles). The studies focus on the function of spiritual care for patients. Spiritual could increase spiritual well-being, quality of life, self-acceptance and meaning of life. Furthermore, spiritual could be used to increase mental health especially for decreasing depression. Spiritual also could increase maternal fetal attachment among pregnant woman. Spiritual care also related to health behavior. However, some studies still showed that nurse did not provide spiritual care for the patients.

Table 1. Overview of spiritual studies among patients

\begin{tabular}{|c|c|c|c|c|c|c|}
\hline Author & Tittle & Country & Sample & Setting & Design & $\begin{array}{l}\text { Focus of } \\
\text { study }\end{array}$ \\
\hline $\begin{array}{l}\text { Phenwan, } \\
\text { 2019 } \\
(18)\end{array}$ & $\begin{array}{l}\text { The meaning } \\
\text { of spirituality } \\
\text { and spiritual } \\
\text { well-being } \\
\text { among Thai } \\
\text { breast cancer } \\
\text { patients: A } \\
\text { qualitative } \\
\text { study }\end{array}$ & Thailand & $\begin{array}{l}16 \text { patients age } \\
\text { over } 18 \text { years old } \\
\text { The result of PPS } \\
\text { (Palliative } \\
\text { performance } \\
\text { scale) more than } \\
50 \text { and no } \\
\text { psychological } \\
\text { diagnosis }\end{array}$ & $\begin{array}{l}\text { Oncology } \\
\text { clinic }\end{array}$ & $\begin{array}{l}\text { Qualitative } \\
\text { descriptive } \\
\text { Phenomenology } \\
\text { design }\end{array}$ & $\begin{array}{l}\text { Respondent } \\
\text { with good } \\
\text { spiritual had } \\
\text { good spiritual } \\
\text { well-being } \\
\text { (SWB) }\end{array}$ \\
\hline $\begin{array}{l}\text { Cheng et al., } \\
\text { 2019(19) }\end{array}$ & $\begin{array}{l}\text { Improving } \\
\text { spiritual well- } \\
\text { being among } \\
\text { cancer } \\
\text { patients: } \\
\text { implications } \\
\text { for clinical } \\
\text { care }\end{array}$ & $\begin{array}{l}\text { ROC } \\
\text { (China) }\end{array}$ & $\begin{array}{l}200 \text { patient with } \\
\text { cancer }\end{array}$ & $\begin{array}{l}\text { Tertiary } \\
\text { Hospital } \\
\text { cancer }\end{array}$ & $\begin{array}{l}\text { Quantitative: } \\
\text { cross-sectional } \\
\text { design }\end{array}$ & $\begin{array}{l}\text { Spiritual had } \\
\text { effect on } \\
\text { quality of life }\end{array}$ \\
\hline $\begin{array}{l}\text { Christian et } \\
\text { al., 2019(20) }\end{array}$ & $\begin{array}{l}\text { How religious } \\
\text { and spiritual } \\
\text { beliefs explain } \\
\text { prolonged } \\
\text { grief disorder } \\
\text { symptoms }\end{array}$ & Australia & $\begin{array}{l}588 \text { prolonged } \\
\text { grief disorder }\end{array}$ & $\begin{array}{l}4 \text { funeral } \\
\text { in } \\
\text { Australia }\end{array}$ & $\begin{array}{l}\text { Quantitative: } \\
\text { cross-sectional } \\
\text { design }\end{array}$ & $\begin{array}{l}\text { Spiritual } \\
\text { related with } \\
\text { meaning of } \\
\text { life }\end{array}$ \\
\hline $\begin{array}{l}\text { Ebenau et al., } \\
\text { 2020(21) }\end{array}$ & $\begin{array}{l}\text { Spiritual care } \\
\text { by nurses in } \\
\text { curative } \\
\text { oncology: a } \\
\text { mixed-method } \\
\text { study on } \\
\text { patients' } \\
\text { perspectives } \\
\text { and } \\
\text { experiences }\end{array}$ & Netherland & $\begin{array}{l}17 \text { oncology } \\
\text { patients in the last } \\
\text { chemotherapy }\end{array}$ & 8 hospitals & $\begin{array}{l}\text { Mix methods: } \\
\text { Quantitative and } \\
\text { qualitative with } \\
\text { semi-structured } \\
\text { interview }\end{array}$ & $\begin{array}{l}\text { Spiritual care } \\
\text { was not in } \\
\text { concern } \\
\text { among nurses }\end{array}$ \\
\hline
\end{tabular}




\begin{tabular}{|c|c|c|c|c|c|c|}
\hline $\begin{array}{l}\text { Ferrel et al., } \\
2019(22)\end{array}$ & $\begin{array}{l}\text { Clinical } \\
\text { Trials: } \\
\text { Understanding } \\
\text { patient } \\
\text { perspectives } \\
\text { and beliefs } \\
\text { about } \\
\text { treatment }\end{array}$ & USA & $\begin{array}{l}30 \text { patients with } \\
\text { palliative care }\end{array}$ & Hospitals & $\begin{array}{l}\text { Qualitative: } \\
\text { interview }\end{array}$ & $\begin{array}{l}\text { Patients } \\
\text { reported that } \\
\text { health care } \\
\text { provider } \\
\text { provided } \\
\text { spiritual } \\
\text { support }\end{array}$ \\
\hline $\begin{array}{l}\text { Grossoehme } \\
\text { et al., } \\
\mathbf{2 0 2 0}(23)\end{array}$ & $\begin{array}{l}\text { Adults with } \\
\text { cystic fibrosis: } \\
\text { spiritual } \\
\text { coping with } \\
\text { lifelong } \\
\text { disease }\end{array}$ & USA & $\begin{array}{l}25 \text { patients with } \\
\text { cystic fibrosis for } \\
6 \text { years }\end{array}$ & $\begin{array}{l}\text { Hospital at } \\
\text { University } \\
\text { of } \\
\text { Cincinnati } \\
\text { College of } \\
\text { Medicine }\end{array}$ & Qualitative & $\begin{array}{l}\text { Spiritual } \\
\text { related with } \\
\text { health } \\
\text { behavior }\end{array}$ \\
\hline $\begin{array}{l}\text { Moghimian } \\
\text { and Irajpour, } \\
2019(24)\end{array}$ & $\begin{array}{l}\text { The } \\
\text { requirements } \\
\text { of hospital- } \\
\text { based spiritual } \\
\text { care for } \\
\text { cancer } \\
\text { patients }\end{array}$ & Iran & $\begin{array}{l}25 \text { patients with } \\
\text { cancer }\end{array}$ & $\begin{array}{l}\text { Out } \\
\text { patients }\end{array}$ & $\begin{array}{l}\text { Qualitative: } \\
\text { semi structure } \\
\text { interview }\end{array}$ & $\begin{array}{l}\text { Spiritual was } \\
\text { needed to take } \\
\text { care the } \\
\text { patients }\end{array}$ \\
\hline $\begin{array}{l}\text { Ramadas and } \\
\text { Simoes, } \\
2019(25)\end{array}$ & $\begin{array}{l}\text { The } \\
\text { relationship } \\
\text { between } \\
\text { mindfulness, } \\
\text { spiritual well- } \\
\text { being and } \\
\text { chronic } \\
\text { depression: } \\
\text { Different } \\
\text { predictors in } \\
\text { distinct phases } \\
\text { of treatment }\end{array}$ & Portugal & $\begin{array}{l}63 \text { patients with } \\
\text { depressive } \\
\text { disorder, } 28 \\
\text { female , } 35 \text { male } \\
\text { Age } 15 \text { - } 57 \text { years } \\
\text { old. }\end{array}$ & $\begin{array}{l}\text { Residentia } \\
1 \text { treatment } \\
\text { center }\end{array}$ & $\begin{array}{l}\text { Experimental } \\
\text { study }\end{array}$ & $\begin{array}{l}\text { Spiritual } \\
\text { decreased } \\
\text { depression }\end{array}$ \\
\hline $\begin{array}{l}\text { Sulung and } \\
\text { Asyura, } \\
\text { 2019(26) }\end{array}$ & $\begin{array}{l}\text { The analysis } \\
\text { of spirituality } \\
\text { of patients } \\
\text { with } \\
\text { HIV/AIDS in } \\
\text { taking lessons } \\
\text { and self- } \\
\text { acceptance }\end{array}$ & Indonesia & $\begin{array}{l}10 \text { patients with } \\
\text { HIV/AIDS }\end{array}$ & $\begin{array}{l}\text { Children } \\
\text { protection } \\
\text { associatio } \\
\mathrm{n}\end{array}$ & $\begin{array}{l}\text { Qualitative } \\
\text { study: in-depth } \\
\text { interview }\end{array}$ & $\begin{array}{l}\text { Spiritual } \\
\text { increased self- } \\
\text { acceptance } \\
\text { among } \\
\text { HIV/AIDS } \\
\text { patients }\end{array}$ \\
\hline $\begin{array}{l}\text { Zahrani et } \\
\text { al., 2020(27) }\end{array}$ & $\begin{array}{l}\text { The } \\
\text { Correlation } \\
\text { between } \\
\text { Spiritual } \\
\text { Health and } \\
\text { Maternal- } \\
\text { Fetal } \\
\text { Attachment } \\
\text { Behaviors in } \\
\text { Pregnant } \\
\text { Women } \\
\text { Referring to } \\
\text { the Health } \\
\text { Centers in } \\
\text { Qazvin, Iran }\end{array}$ & Iran & $\begin{array}{l}200 \text { pregnant } \\
\text { women }\end{array}$ & $\begin{array}{l}\text { Health } \\
\text { center }\end{array}$ & Quantitative & $\begin{array}{l}\text { Spiritual } \\
\text { related with } \\
\text { behavior of } \\
\text { maternal fetal } \\
\text { attachment }\end{array}$ \\
\hline
\end{tabular}




\section{Nurses and Care Giver}

The review showed that 7 articles focuses on spiritual care that used by nurses and family caregiver (Table 2). The studies come from Iran (1 article), Australia (1 article), Thailand (1 article), India ( 1 article), USA (1 article), and Brazil (1 article). The majority of study setting in this review in intensive care unit (ICU and PICU) ( 3 articles). The predominant of the design of the studies in this review used qualitative study ( 5 articles). The studies focused on the evaluation of spiritual care that was conducted by nurses or family care givers for caring the patients or the families. The result of the review showed that spiritual care was the source of the coping and resilience for patients, so nurses were expected to give the spiritual care among the patients or care givers. Furthermore spiritual care was needed for care giver to make decision for their family who undergoing treatment. In addition, spiritual also being a constructed of well-being.

Table 2. . Overview of spiritual studies among nurses and care giver

\begin{tabular}{|c|c|c|c|c|c|c|}
\hline Author & Title & Country & Sample & Setting & $\begin{array}{l}\text { Desig } \\
\text { n }\end{array}$ & Focus of Study \\
\hline $\begin{array}{l}\text { Galehdar et } \\
\text { al., } 2020 \\
(28)\end{array}$ & $\begin{array}{l}\text { Exploring nurses' } \\
\text { perception about the } \\
\text { care needs of patients } \\
\text { with COVID-19: a } \\
\text { qualitative study }\end{array}$ & Iran & $\begin{array}{l}20 \text { nurses who } \\
\text { take care } \\
\text { patients with } \\
\text { COVID-19 }\end{array}$ & $\begin{array}{l}\text { COVID-19 } \\
\text { ward }\end{array}$ & $\begin{array}{l}\text { Quali } \\
\text { tative }\end{array}$ & $\begin{array}{l}\text { Nurses reported that } \\
\text { spiritual is needed in } \\
\text { nursing care } \\
\text { especially for caring } \\
\text { patients with } \\
\text { COVID-19 }\end{array}$ \\
\hline
\end{tabular}

\begin{tabular}{|c|c|c|c|c|c|c|}
\hline $\begin{array}{l}\text { Jones et al., } \\
2020(29)\end{array}$ & $\begin{array}{l}\text { Rehabilitation health } \\
\text { professionals' } \\
\text { perceptions of } \\
\text { spirituality and spiritual } \\
\text { care: The results of an } \\
\text { online survey }\end{array}$ & Australia & $\begin{array}{l}125 \text { nurses in } \\
\text { rehabilitation }\end{array}$ & $\begin{array}{l}\text { Rehabilitati } \\
\text { on unit }\end{array}$ & $\begin{array}{l}\text { Quan } \\
\text { titativ } \\
\text { e }\end{array}$ & $\begin{array}{l}\text { There were staffs } \\
\text { who did not give } \\
\text { spiritual care in } \\
\text { rehabilitation unit }\end{array}$ \\
\hline $\begin{array}{l}\text { Pattaranuc } \\
\text { h et al., } \\
2020(30)\end{array}$ & $\begin{array}{l}\text { End-of-Life Care for } \\
\text { Children and Families } \\
\text { in Pediatric Intensive } \\
\text { Care: Thai Nurses' } \\
\text { Perspectives }\end{array}$ & Thailand & 24 nurses & $\begin{array}{l}\text { ICU for } \\
\text { children }\end{array}$ & $\begin{array}{l}\text { Quali } \\
\text { tative }\end{array}$ & $\begin{array}{l}\text { Spiritual is needed } \\
\text { for caring children in } \\
\text { the end-of-life }\end{array}$ \\
\hline $\begin{array}{l}\text { Moss et al., } \\
2019(31)\end{array}$ & $\begin{array}{l}\text { Family Surrogate } \\
\text { Decision-making in } \\
\text { Chronic Critical Illness: } \\
\text { A Qualitative Analysis }\end{array}$ & USA & $\begin{array}{l}7 \text { family } \\
\text { surrogate who } \\
\text { make decision } \\
\text { for their } \\
\text { family }\end{array}$ & ICU & $\begin{array}{l}\text { Quali } \\
\text { tative }\end{array}$ & $\begin{array}{l}\text { Spiritual is coping } \\
\text { source in decision } \\
\text { making for their } \\
\text { family with chronic } \\
\text { illness }\end{array}$ \\
\hline $\begin{array}{l}\text { Pandya, } \\
2019 \text { (32) }\end{array}$ & $\begin{array}{l}\text { Spiritual education } \\
\text { programed for primary } \\
\text { caregiver parents to } \\
\text { build resilience in } \\
\text { children with acute } \\
\text { anxiety symptoms: A } \\
\text { multicity study }\end{array}$ & India & $\begin{array}{l}3,689 \text { parents } \\
\text { who become } \\
\text { primary care } \\
\text { giver for their } \\
\text { children who } \\
\text { diagnosis } \\
\text { with anxiety }\end{array}$ & 15 schools & $\begin{array}{l}\text { Expe } \\
\text { rimen } \\
\text { tal } \\
\text { study }\end{array}$ & $\begin{array}{l}\text { Spiritual had effect } \\
\text { on resiliency }\end{array}$ \\
\hline $\begin{array}{l}\text { Verri et al., } \\
2019(33)\end{array}$ & $\begin{array}{l}\text { Nursing Professionals: } \\
\text { Understanding About } \\
\text { Pediatric Palliative Care }\end{array}$ & Brazil & 30 nurses & $\begin{array}{l}\text { PICU, } \\
\text { Pediatric } \\
\text { oncology }\end{array}$ & $\begin{array}{l}\text { Quali } \\
\text { tative } \\
: \\
\text { semi }\end{array}$ & $\begin{array}{l}\text { Spiritual is needed } \\
\text { for coping in } \\
\text { palliative care }\end{array}$ \\
\hline
\end{tabular}




\begin{tabular}{|c|c|c|c|c|c|}
\hline & & & $\begin{array}{l}\text { clinic and } \\
\text { hospital }\end{array}$ & $\begin{array}{l}\text { struct } \\
\text { ured } \\
\text { interv } \\
\text { iew }\end{array}$ & \\
\hline $\begin{array}{l}\text { Dalir et al., } \\
2020(34)\end{array}$ & $\begin{array}{l}\text { Coping with Caregiving Iran } \\
\text { Stress in Families of } \\
\text { Children with } \\
\text { Congenital Heart } \\
\text { Disease: A Qualitative } \\
\text { Study }\end{array}$ & $\begin{array}{l}40 \\
\text { respondents } \\
\text { from family } \\
\text { who have } \\
\text { children with } \\
\text { congenital } \\
\text { heart disease }\end{array}$ & $\begin{array}{l}\text { Cardiology } \\
\text { hospital }\end{array}$ & $\begin{array}{l}\text { Quali } \\
\text { tative } \\
: \\
\text { In } \\
\text { depth } \\
\text { interv } \\
\text { iew } \\
\text { and } \\
\text { semi- } \\
\text { struct } \\
\text { ured } \\
\text { interv } \\
\text { iew }\end{array}$ & $\begin{array}{l}\text { Wellbeing was } \\
\text { developed by } \\
\text { construct, namely } \\
\text { spiritual. }\end{array}$ \\
\hline
\end{tabular}

\section{Patients and care giver}

The review showed that two articles focused on patients and caregivers. The setting of the studies were hospital and community setting. The studies come from Iran and Canada. The result of the studies were obtained from the patients or care giver's reports. The studies showed that spiritual care was needed in caring patients with cancer. Also spiritual care should be inserted into nursing curriculum or education.

Table 3. Overview of spiritual care study among patients and care givers

\begin{tabular}{|c|c|c|c|c|c|c|}
\hline Author & Tittle & Country & Sample & Setting & Design & Focus of study \\
\hline $\begin{array}{l}\text { Moosavi et al., } \\
2019(35)\end{array}$ & $\begin{array}{l}\text { Factors } \\
\text { affecting } \\
\text { spiritual } \\
\text { care } \\
\text { practices } \\
\text { of } \\
\text { oncology } \\
\text { nurses: a } \\
\text { qualitativ } \\
\text { e study }\end{array}$ & Iran & $\begin{array}{l}25 \\
\text { respondents, } \\
\text { namely } \\
\text { patients with } \\
\text { cancer and } \\
\text { their family. } \\
\text { Oncology } \\
\text { nurses, } \\
\text { physician, } \\
\text { psychologist } \\
\text { and spiritual } \\
\text { therapist. }\end{array}$ & $\begin{array}{l}\text { Oncology } \\
\text { department in } 3 \\
\text { Teaching } \\
\text { Hospitals }\end{array}$ & $\begin{array}{l}\text { Qualitative } \\
\text { study with semi } \\
\text { structure } \\
\text { interview }\end{array}$ & $\begin{array}{l}\text { Spiritual care } \\
\text { was needed at } \\
\text { hospital and } \\
\text { must inserted } \\
\text { in the nursing } \\
\text { curriculum as } \\
\text { well as in the } \\
\text { nursing } \\
\text { education }\end{array}$ \\
\hline $\begin{array}{l}\text { Gifford et al., } \\
2019 \text { (36) }\end{array}$ & $\begin{array}{l}\text { Spirituali } \\
\text { ty in } \\
\text { cancer } \\
\text { survivors } \\
\text { hip with } \\
\text { First } \\
\text { Nations } \\
\text { people in } \\
\text { Canada }\end{array}$ & Canada & $\begin{array}{l}29 \text { cancer } \\
\text { survivor and } \\
2 \text { family } \\
\text { caregiver }\end{array}$ & Communities & Qualitative & $\begin{array}{l}\text { Spiritual was } \\
\text { needed for } \\
\text { struggling and } \\
\text { surviving } \\
\text { among patient } \\
\text { with cancer }\end{array}$ \\
\hline
\end{tabular}




\section{Discussion}

The aim of this study was to review the papers related to spiritual care, so it can be used as a guideline for nursing, nursing practice and achieve a holistic care. In this study, we included 19 papers. The results of the study showed that clients or patients who receive spiritual care could enhance quality of life as well as meaning of life. Further, the clients or patients can take lessons from their illnesses, and also more accepting of their life conditions (self-acceptance). The results of the review showed that spiritual care is needed in the nursing care for patients as well as for nurses and caregivers to improve the quality of nursing and achieve physical and mental health. In addition, spiritual care can also be used as coping when facing stressors. However, on the other hand, several studies still report that spiritual care was not provided and delivered by nurses.

The results of this review were in line with previous systematic review which mentioned that spiritual and spiritual care were needed for implementing holistic nursing care to achieve quality of life (37). The paper showed that spiritual care was related to the patient's spiritual well-being (18). One of the results of the papers also showed that well-being is developed by the spiritual domain (34). In addition spiritual influenced the quality of life (19), related to meaning of life (20) self-acceptance $(26)$, and healthy behavior $(38,27)$ (table 1, table 3 ). Based on these papers, it can be concluded that spiritual care is needed by patients, so it was needed to depict clear definition of spiritual care.

Spiritual care was also needed by patients with mental illness. The result of the review showed that spiritual care was needed to reduce the level of depression among patients diagnosed with depressive disorders(25). Spiritual care is necessary not only for physical health but also for patients with mental illness

The review showed that spirituality is needed for nurses and caregivers who take care their families for increasing coping and resilience (table 2, table 3). Furthermore, spiritual care can be used by nurses or caregivers for developing their coping when dealing with patients, because spirituality can control their psychological when facing occupational stress $(32,34)$. Spiritual care could also be used by caregivers to decide the treatment related to patients (31). The results of this review also in line with previous research which mentioned that the importance of spiritual care in the nursing care (39). So it can be concluded that spiritual care was not only needed by the patients but also it had a positive effect among nurse or caregiver to increase their hope.

The results of the review were also predominant by paper which mentioned that spiritual care was needed by patients with chronic and high mortality prevalence disease, such as cancer (18,40, 41,35, 42), HIV (43), and congenital heart disease (44). Spiritual care can also be used in patients with new types of diseases such as COVID-19 (45). Further, it very necessary for palliative care (46). Spiritual and spiritual care were the power to struggle and survive from the illness. 
Based on the review, spiritual care in providing holistic nursing care was an important aspect, so spiritual care should be provided by nurses and included in the curriculum in nursing education (35). However, the results of the review mentioned that there were still many nurses who do not provide spiritual care $(40,47)$. We assume that there are still many nurses who have not updated or they did not know the definition of spiritual as well spiritual care.

The studies in this review came from the European continent (Netherlands and Portugal), America (USA, Brazil and Canada), Australia, and it were dominated by Asia (Indonesia, Thailand, India, Iran, and China). Many studies was conducted in Iran. We still did not find the evidence why the spiritual studies came from Iran. However, the majority of Iran's population is Muslim (48). We assume that they conducted religious rituals and do not separate religious activities in their daily activities. Religious activity is a part of the spiritual (6). The results of the review also showed that Indonesia had one evidence related to spiritual care. We assume that Indonesia actually has many spiritual care studies however it was not in English language (49)).

This review used one data base (CINAHL database) which focus on nursing science. However, this review covered papers related to spiritual care from various countries in the world. In addition the papers also mentioned that the importance of spiritual care for mental health, physical health, well-being, quality of life, and also increasing expectations to recovery among patients, nurses or caregivers. Further research should be able to focus on the definition and concept of spiritual care in accordance with the culture of each country.

\section{Conclusion}

This review provides a new insight related to the importance of spiritual care in nursing care practices. Spiritual care could increase physical and mental health, well-being, meaning of life as well as quality of life among patients, nurses and care givers. Further, spiritual care could develop a new hope for terminal patients also being a coping for nurses and caregivers. Therefore, spiritual care is needed when conducting nursing care to gain the holistic care. 


\section{REFERENCE}

1. Ramenzani, A; Ahmadi, F; Mohammadi, E; Kazemnejad A. Spiritual Care In Nursing : A Concept Analysis International Nursing Review. Int Nurs Rev. 2014;61(2):211-9.

2. Cook NF, Elliot M. Providing Holistic Care. In: Fundamentals of Person-Centred Healthcare Practice. Wiley-Blackwell Publishing Ltd; 2020. p. 147.

3. Govier I. Spiritual care in nursing: a systematic approach. Nurs Stand (through 2013). 2000;14(17):32.

4. Monareng L V. Spiritual nursing care: A concept analysis. Curationis. 2012;35(1):1-9.

5. Ramezani M, Ahmadi F, Mohammadi E, Kazemnejad A. Spiritual care in nursing: a concept analysis. Int Nurs Rev. 2014;61(2):211-9.

6. International N. NANDA INTERNATIONAL NURSING DIAGNOSES [Internet]. Vol. 2021. 2018. Available from: https://nanda.org/publications-resources/publications/nandainternational-nursing-diagnoses-definitions-classification-2018-2020/

7. Karaman E, Erkin Ö, Göl İ. The Relationship Between Spiritual Care Levels of Turkish Nurses with the Spiritual Well-Being of Their Patients: An Exploratory Study. J Relig Health. 2021;1-12.

8. Ho JQ, Nguyen CD, Lopes R, Ezeji-Okoye SC, Kuschner WG. Spiritual care in the intensive care unit: a narrative review. J Intensive Care Med. 2018;33(5):279-87.

9. Reed PG. An emerging paradigm for the investigation of spirituality in nursing. Res Nurs Health. 1992;15(5):349-57.

10. Nurses IC of, ICN. Code of Ethics for Nurses [Internet]. Geneva; 2012. Available from: https://www.icn.ch/sites/default/files/inline-files/2012_ICN_Codeofethicsfornurses_ eng.pdf

11. Ross L. Spiritual care in nursing: an overview of the research to date. J Clin Nurs. 2006;15(7):852-62.

12. Wilfred $\mathrm{M}$. The principal components model: a model for advancing spirituality and spiritual care within nursing and health care practice. J Clin Nurs. 2006;15(7):905-17.

13. van de Geer J, Groot M, Andela R, Leget C, Prins J, Vissers K, et al. Training hospital staff on spiritual care in palliative care influences patient-reported outcomes: Results of a quasi-experimental study. Palliat Med. 2017;31(8):743-53.

14. Gillilan R, Qawi S, Weymiller AJ, Puchalski C. Spiritual distress and spiritual care in advanced heart failure. Heart Fail Rev. 2017;22(5):581-91.

15. Musa AS, Pevalin DJ, Al Khalaileh MAA. Spiritual well-being, depression, and stress among hemodialysis patients in Jordan. J Holist Nurs. 2018;36(4):354-65.

16. Matos TD de S, Meneguin S, Ferreira M de L da S, Miot HA. Quality of life and religious-spiritual coping in palliative cancer care patients. Rev Lat Am Enfermagem. 2017;25.

17. Hall P, Bacheller LL, Desir C. Spirituality and psychological well-being in adults of Haitian descent. Ment Health Relig Cult. 2019;22(5):453-66.

18. Phenwan Peerawong \& Tulathamkij, K., T T. The meaning of spirituality and spiritual well-being among thai breast cancer patients: A qualitative study. Indian J Palliat Care [Internet]. 2019;25(1):119-23. Available from: http://search.ebscohost.com/login.aspx?direct=true \&db=rzh\&AN=134424566\&site=ehost -live

19. Cheng Q, Liu X, Li X, Wang Y, Mao T, Chen Y. Improving spiritual well-being among 
cancer patients: implications for clinical care. Support Care Cancer [Internet]. 2019;27(9):3403-9. Available from:

http://search.ebscohost.com/login.aspx?direct=true $\& d b=r z h \& A N=137721574 \&$ site=ehost -live

20. Christian KM, Aoun SM, Breen LJ. How religious and spiritual beliefs explain prolonged grief disorder symptoms. Death Stud [Internet]. 2019;43(5):316-23. Available from: https://doi.org/10.1080/07481187.2018.1469054

21. Ebenau A, Groot M, Visser A, Laarhoven HWM, Leeuwen R, Garssen B. Spiritual care by nurses in curative oncology: a mixed-method study on patients' perspectives and experiences. Scand J Caring Sci [Internet]. 2020 Mar;34(1):96-107. Available from: http://search.ebscohost.com/login.aspx?direct=true \&db=rzh\&AN=141997558\&site=ehost -live

22. Ferrell B, Williams AC, Borneman T, Chung V, Smith TJ. Clinical Trials: Understanding patient perspectives and beliefs about treatment. Clin J Oncol Nurs [Internet]. 2019 Dec;23(6):592-8. Available from: http://search.ebscohost.com/login.aspx?direct=true \&db=rzh\&AN=139713156\&site=ehost -live

23. Grossoehme DH, Cole AG, Lewis K, Stamper SM, Teeters A, Joseph PM. Adults with cystic fibrosis: spiritual coping with lifelong disease. J Health Care Chaplain [Internet]. 2020;26(2):45-57. Available from:

http://search.ebscohost.com/login.aspx?direct=true \&db=rzh\&AN=142454841\&site=ehost -live

24. Moghimian M, Irajpour A. The requirements of hospital-based spiritual care for cancer patients. Support Care Cancer [Internet]. 2019 Jul;27(7):2643-8. Available from: http://search.ebscohost.com/login.aspx?direct=true \&db=rzh\&AN=136714723\&site=ehost -live

25. Ramadas E, Simões SC. The relationship between mindfulness, spiritual well-being and chronic depression: Different predictors in distinct phases of treatment. Couns Psychother Res [Internet]. 2019 Jun;19(2):138-48. Available from: http://search.ebscohost.com/login.aspx?direct=true \&db=rzh\&AN=135862270\&site=ehost -live

26. Sulung N, Asyura R. The analysis of spirituality of patients with HIV/AIDS in taking lessons and self-acceptance. Indian J Palliat Care [Internet]. 2019 Apr;25(2):232-5. Available from: http://search.ebscohost.com/login.aspx?direct=true \&db=rzh\&AN=135968379\&site=ehost -live

27. Zahrani ST, Rafiei EH, Hajian S, Majd HA, Izadi A. The Correlation between Spiritual Health and Maternal-Fetal Attachment Behaviors in Pregnant Women Referring to the Health Centers in Qazvin, Iran. Int J Community Based Nurs Midwifery [Internet]. 2020 Jan;8(1):84-91. Available from:

http://search.ebscohost.com/login.aspx?direct=true \&db=rzh\&AN=141706887\&site=ehost -live

28. Galehdar N, Toulabi T, Kamran A, Heydari H. Exploring nurses' perception about the care needs of patients with COVID-19: a qualitative study. BMC Nurs [Internet]. 2020;19(1):1-8. Available from: http://search.ebscohost.com/login.aspx?direct=true \&db=rzh\&AN=147544517\&site=ehost 
-live

29. Jones KF, Pryor J, Care-Unger C, Simpson GK, Dein S. Rehabilitation health professionals' perceptions of spirituality and spiritual care: The results of an online survey. NeuroRehabilitation [Internet]. 2020 Jan;46(1):17-30. Available from: $\mathrm{http}: / /$ search.ebscohost.com/login.aspx?direct=true $\& \mathrm{db}=\mathrm{rzh} \& \mathrm{AN}=142008702 \&$ site=ehost -live

30. Pattaranuch P, Warunee F, Jutarat M, Srimana N. End-of-Life Care for Children and Families in Pediatric Intensive Care: Thai Nurses' Perspectives. Pacific Rim Int J Nurs Res [Internet]. 2020;24(3):335-48. Available from:

http://search.ebscohost.com/login.aspx?direct=true \&db=rzh\&AN=144611052\&site=ehost -live

31. Moss KO, Douglas SL, Baum E, Daly B. Family Surrogate Decision-making in Chronic Critical Illness: A Qualitative Analysis. Crit Care Nurse [Internet]. 2019 Jun;39(3):e1826. Available from: http://search.ebscohost.com/login.aspx?direct=true\&db=rzh\&AN=136783766\&site=ehost -live

32. Pandya SP. Spiritual education programme for primary caregiver parents to build resilience in children with acute anxiety symptoms: A multicity study. Child Fam Soc Work. 2019;24(2):309-20.

33. Verri ER, Santana Bitencourt NA, da Silva Oliveira JA, dos Santos Júnior R, Silva Marques H, Alves Porto $M$, et al. NURSING PROFESSIONALS: UNDERSTANDING ABOUT PEDIATRIC PALLIATIVE CARE. J Nurs UFPE / Rev Enferm UFPE [Internet]. 2019 Jan;13(1):126-36. Available from:

http://search.ebscohost.com/login.aspx?direct=true \&db=rzh\&AN=134018737\&site=ehost -live

34. Dalir Z, Heydari A, Kareshki H, Manzari ZS. Coping with Caregiving Stress in Families of Children with Congenital Heart Disease: A Qualitative Study. Int J Community Based Nurs Midwifery [Internet]. 2020 Apr;8(2):127-39. Available from:

http://search.ebscohost.com/login.aspx?direct=true \&db=rzh\&AN=142714444\&site=ehost -live

35. Moosavi S, Rohani C, Borhani F, Akbari ME. Factors affecting spiritual care practices of oncology nurses: a qualitative study. Support Care Cancer [Internet]. 2019;27(3):901-9. Available from: http://search.ebscohost.com/login.aspx?direct=true\&db=rzh\&AN=134564339\&site=ehost -live

36. Gifford W, Thomas O, Thomas R, Grandpierre V, Ukagwu C. Spirituality in cancer survivorship with First Nations people in Canada. Support Care Cancer [Internet]. 2019;27(8):2969-76. Available from:

http://search.ebscohost.com/login.aspx?direct=true \&db=rzh\&AN=137207657\&site=ehost -live

37. Chen J, Lin Y, Yan J, Wu Y, Hu R. The effects of spiritual care on quality of life and spiritual well-being among patients with terminal illness: a systematic review. Palliat Med. 2018;32(7):1167-79.

38. Grossoehme DH, Cole AG, Lewis K, Stamper SM, Teeters A, Joseph PM. Adults with cystic fibrosis: spiritual coping with lifelong disease. J Health Care Chaplain [Internet]. 2020 Apr;26(2):45-57. Available from: 
http://search.ebscohost.com/login.aspx?direct=true\&db=rzh\&AN=142454841\&site=ehost -live

39. Rachel H, Chiara C, Robert K, Francesco S. Spiritual care in nursing: an overview of the measures used to assess spiritual care provision and related factors amongst nurses. Acta Bio Medica Atenei Parm. 2019;90(Suppl 4):44.

40. Ebenau A, Groot M, Visser A, Laarhoven HWM, Leeuwen R, Garssen B. Spiritual care by nurses in curative oncology: a mixed-method study on patients' perspectives and experiences. Scand J Caring Sci [Internet]. 2020;34(1):96-107. Available from:

http://search.ebscohost.com/login.aspx?direct=true \&db=rzh\&AN=141997558\&site=ehost -live

41. Moghimian M, Irajpour A. The requirements of hospital-based spiritual care for cancer patients. Support Care Cancer [Internet]. 2019;27(7):2643-8. Available from:

http://search.ebscohost.com/login.aspx?direct=true \&db=rzh\&AN=136714723\&site=ehost -live

42. Gifford W, Thomas O, Thomas R, Grandpierre V, Ukagwu C. Spirituality in cancer survivorship with First Nations people in Canada. Support Care Cancer [Internet]. 2019 Aug;27(8):2969-76. Available from:

http://search.ebscohost.com/login.aspx?direct=true \&db=rzh\&AN=137207657\&site=ehost -live

43. Sulung N, Asyura R. The analysis of spirituality of patients with HIV/AIDS in taking lessons and self-acceptance. Indian J Palliat Care [Internet]. 2019;25(2):232-5. Available from:

http://search.ebscohost.com/login.aspx?direct=true\&db=rzh\&AN=135968379\&site=ehost -live

44. Dalir Z, Heydari A, Kareshki H, Manzari ZS. Coping with caregiving stress in families of children with congenital heart disease: A qualitative study. Int J Community Based Nurs Midwifery. 2020;8(2):127-39.

45. Galehdar N, Toulabi T, Kamran A, Heydari H. Exploring nurses' perception about the care needs of patients with COVID-19: a qualitative study. BMC Nurs [Internet]. 2020 Dec 11;19(1):1-8. Available from:

http://search.ebscohost.com/login.aspx?direct=true \&db=rzh\&AN=147544517\&site=ehost -live

46. Cheng Q, Liu X, Li X, Wang Y, Mao T, Chen Y. Improving spiritual well-being among cancer patients: implications for clinical care. Support Care Cancer [Internet]. 2019 Sep;27(9):3403-9. Available from:

http://search.ebscohost.com/login.aspx?direct=true $\& d b=$ rzh\&AN=137721574\&site=ehost -live

47. Jones KF, Pryor J, Care-Unger C, Simpson GK. Rehabilitation health professionals' perceptions of spirituality and spiritual care: The results of an online survey. NeuroRehabilitation. 2020;46(1):17-30.

48. Sarafan N 'Lily.' The Evolving Nexus between Islam and Iran [Internet]. Vol. 2021. 2001. Available from: https://web.stanford.edu/class/e297a/Islam and Iran.htm

49. Nuraeni A, Nurhidayah I, Hidayati N, Sari CWM, Mirwanti R. Kebutuhan spiritual pada pasien kanker. J Keperawatan Padjadjaran. 2015;3(2). 